\title{
Estruturas comunicativas na textualidade teatral além do drama rigoroso - a crise do drama em dois textos teatrais brasileiros do fim dos anos 80
}

Stepahn Arnulf Baugartel

\section{Resumo}

Partindo do pressuposto de que todo texto teatral é marcado por um sistema comunicativo duplo, esse artigo define como textualidade especificamente teatral aquela que joga conscientemente com os dois eixos da comunicação teatral, o eixo intracênico e o eixo palco-plateia. Aponta que a dramaturgia contemporânea radicaliza o eixo palco-platéia e fortalece a importância desse eixo enquanto exposição de estruturas performativas do texto. Desse modo chega-se a uma compreensão do texto não-mais-dramático que não se limita à transgressão das unidades dramáticas de tempo, lugar e ação. A seguir, o artigo analisa textos de dois autores brasileiros, Mauro Rasi e Alcides Nogueira, na perspectiva da manipulação dos eixos comunicativos, para posicioná-los criticamente na dinâmica da crise do drama no Brasil.

Palavras-Chave: Dramaturgia não-mais-dramática; crise do drama; comunicação teatral; Mauro Rasi; Alcides Nogueira; Mário Bortolotto

\section{Abstract}

Starting from the presupposition that every written theatrical text is marked by a double communicative system, this article defines as a specifically theatrical textuality that which plays consciously with the two vectors of theatrical communication, being one intra-scenic and the other orientated towards the audience. It discusses contemporary dramaturgy as a radicalization of the axis between stage and audience as a possibility to expose the performative structure of the text. In doing so, one can come to an understanding of non-dramatic theatrical writing that is not limited by the mere transgression of the three dramatic unities of time, space and action. Subsequently, the article analyses plays by two Brazilian authors, Mauro Rasi e Alcides Nogueira, as far as their manipulation of the communicative structure is concerned, in order to position these plays critically within the dynamics of the crisis of drama in Brazil.

Keywords: Non-dramatic theatrical writing; the crisis of drama; theatrical communication; Mauro Rasi; Alcides Nogueira; Mário Bortolotto

\section{A dupla comunicação da textualidade teatral enquanto sintoma de uma} dramaturgia além do drama rigoroso. Peter Szondi (2001, p.31) apontou como uma das características do drama o fato de que ele configura o espaço cênico enquanto espaço fechado. Consequentemente, o texto dramático ${ }^{1}$ e sua apresentação teatral

\footnotetext{
'Quando uso o adjetivo "dramático", sempre me refiro ao gênero teatral do drama, e não à qualidade emocional daquilo que é cheio de suspense e conflito. Me refiro a um modo de representação teatral que tem como modelo emblemático o drama burguês realista com forte influência da poética aristotélica que ganhou hegemonia cultural a partir de Diderot e cuja dominância incontestada durou até a virada para o século XX.
} 
no formato de drama levam em conta quase unicamente a comunicação intraficcional. Nesse particular, a salvação do drama através da incorporação de características épicas e líricas à serviço do drama, tal como constatada por Szondi na referida obra, fragmenta, multiplica e pulveriza a unidade do tempo e do espaço ficcional, mas não necessariamente instala a comunicação entre palco e espectadores no mesmo nível de importância e com a mesma ênfase que a comunicação intraficcional. No livro de Szondi percebe-se que o drama moderno é marcado por uma crescente tensão entre estes dois eixos de comunicação, sem que se rompa com a dominância do eixo ficcional. Nos exemplos da crise do drama, comentados por Szondi, encontramos um uso do diálogo que visa mostrar e expor as falas não enquanto portadoras de uma ação e narrativa ficcional, mas enquanto sintomas de uma indagação num estado existencial. Nesse sentido podemos constatar que o projeto dramatúrgico desses exemplos foi marcado pela tentativa de mostrar, no funcionamento e na performatividade de uma linguagem textual, o drama existencial tal como visto pela cosmovisão do autor. A performatividade da linguagem substitui até certo ponto funções assumidas anteriormente pelo aspecto representacional da linguagem. Disso decorre a falta de ação ficcional em textos de autores como Ibsen, Maeterlinck e Tchekhov.

Tanto no caso desses autores quanto nos autores da "salvação do drama", como O'Neill, Wilder, Miller, ou Brecht na sua fase épica, a representação ainda se sobrepõe à apresentação e à performatividade, a ilusão dramática se impõe ao Gestus interrogativo. Entretanto, a comunicação teatral é por definição uma comunicação dupla: a comunicação entre os personagens (no plano da ficção) e a comunicação entre palco e plateia (ou seja, entre os artistas e os espectadores) acontecem simultaneamente. ${ }^{2}$ Essa característica é constitutiva sobretudo para o teatro, mas também, em certo grau, para a televisão e o cinema. Entretanto, devido ao status do teatro enquanto uma arte ao vivo, o jogo cênico permite uma ênfase específica no eixo palco-theatron. $O$ texto escrito, por meio de sua estrutura representacional, de fato organiza a relação entre os dois eixos no âmbito da escrita, sem que esse fato implique necessariamente em um novo textocentrismo no palco. A apresentação cênica de um texto sempre pode

\footnotetext{
2 Ver Ryngaert (1996, p.109), Pfister (1988, p.24), e implicitamente também Sarrazac (2002, original francês 1981) com a noção do texto teatral rapsódico. O eixo comunicativo entre palco e plateia, denominado por Hans-Thies Lehmann de eixo theatron, não pode ser reduzido à relação entre o autor e o leitor. Não é que nele encontrase a posição implícita do autor, como uma análise textocentrista às vezes ainda nos quer fazer crer. O que nos interessará aqui é a relação móvel entre os dois eixos, proposta pela escrita teatral contemporânea, de modo que o autor enquanto centro de enunciação do texto se desfaz na multiplicidade das posições de escrita.
} 
subverter ou transgredir o modo como este organiza, em sua escrita verbal (o texto falado) e não-verbal (especialmente as didascálias), a comunicação dupla, como atestam montagens contemporâneas de textos canônicos do teatro burguês, que se afastam radicalmente do modo realista e tradicionalmente dramático de encenação.

O que me interessa nesse artigo é discutir como a configuração formal de textos teatrais contemporâneos coloca um enfoque específico na comunicação teatral enquanto essa dupla comunicação. Localizo nesses traços formais uma textualidade especificamente teatral. Ela ultrapassa as características do gênero dramático enquanto narrativa apresentada em forma dialogada, definição apresentada por Aristóteles, para diferenciar a narrativa do dramático das narrativas e descrições do épico e do lírico. De fato, a definição de Aristóteles não me parece ser errônea, mas a partir de um ponto de vista contemporâneo, ela sofre de um defeito que é mais bem entendido como um vício de leitura estabelecido durante os séculos do reinado do teatro burguês realista. Isto é, ela reduz a dimensão do diálogo às falas entre os personagens ficcionais como se fossem representantes da cosmovisão burguesa. ${ }^{3}$ Mas com o declínio da escrita realista e o surgimento de uma escrita mais abstrata e simbolista no final do século XIX, iniciou-se um processo de escrita dramatúrgica que ampliou o significado dessa "forma dialogada" e incluiu na estrutura dramatúrgica também o eixo comunicativo com o público, de modo a criar efeitos estéticos e reflexivos exatamente a partir da copresença problemática desses dois eixos. Essa copresença permite não só, como no gestus Brechtiano, expor para o olhar crítico dos espectadores a narrativa e as ações dos personagens, mas as falas - expor a língua enquanto estrutura verbal objetiva que atravessa o sujeito falante. A figura em cena vira tanto agente enunciante dessa estrutura quanto sujeito que é sujeito à estrutura da linguagem verbal.

Esse desdobramento dramatúrgico do duplo diálogo teatral é perceptível já em peças simbolistas, como Os cegos (1890) de Maurice Maeterlinck. Ele se alastra pelo

\footnotetext{
${ }^{3}$ A querelle durante o neoclassicismo francês de como interpretar a proposta Aristotélica acerca do tempo adequado da apresentação, que gira em torno da relação entre tempo da apresentação e o tempo apresentado, mostra que naquele momento histórico havia uma consciência e uma tensão admitida entre os dois eixos de comunicação. Igualmente, uma leitura atenta das tragédias gregas mostra claramente que não só o coro, mas também os personagens individuais têm longas passagens que são mais bem entendidas como endereçadas ao público (ou aos deuses), e não a uma personagem ficcional. A comparação entre a tragédia grega e o drama burguês deixa igualmente claro que a fala dialogada da tragédia grega não implica que os enunciadores das falas sejam personagens no sentido psicológico burguês. A dramaturgia contemporânea, na medida em que ela se coloca além do drama, realiza uma pesquisa acerca das possibilidades de trabalhar com estruturas dialógicas sem que elas impliquem 'personagens'. A este ponto, ver também Abirached, 1994.
} 
corpus dramático que estabelece um uso crítico do modelo realista burguês e que inclui autores tão distintos em seus traços formais como Tchekhov, Brecht, Genet, e Beckett, para nomear alguns autores cuja escrita teatral evidencia o problema da comunicação teatral como constitutiva da sua forma. ${ }^{4}$ Com estes nomes também quero afirmar que não é necessário evocar uma dramaturgia pós-moderna e pós-estruturalista, que transforma sujeitos figurativos em portadores de fragmentos discursivos, ${ }^{5}$ para encontrar uma ênfase especial, por meio da escrita e do texto falado, nas dimensões da língua que escapem ao nível figurativo e estritamente intraficcional. Pois a coexistência dos dois eixos comunicativos se faz presente, sempre quando a retórica da escrita textual nos convida, enquanto leitores e espectadores, a observar como a linguagem verbal age enquanto força criativa da realidade estética teatral. Essa dupla linguagem sabe e admite que não representa o mundo empírico, mas faz o leitor e espectador experimentar e perceber inusitadamente o mundo empírico por meio da experiência da escrita teatral. ${ }^{6}$ A experiência do mundo empírico passa pela forma da escrita, que por sua vez, por meio da ênfase na dupla comunicação teatral, substitui o agon ficcional da narrativa por um agon constituído pelos modos de apresentação e de percepção do evento teatral. Neste artigo, nos interessará como a dramaturgia escrita pode incorporar esse outro agon e jogar com ele. Como há poucos estudos dramatúrgicos da dramaturgia contemporânea brasileira, buscarei fechar um pouco essa lacuna e exemplificar posteriormente minhas reflexões com exemplos de autores brasileiros.

Performatividade e textualidade na retórica da escrita teatral. Definir a manipulação consciente do cruzamento dos dois eixos de comunicação no interior do texto teatral (dramático e não-dramático) enquanto textualidade especificamente teatral implica em focar a atenção não só em questões temáticas e actanciais da ficção, ${ }^{7}$ mas também em questões formais do texto intimamente ligadas à apresentação cênica. Tais qualidades formais são, por exemplo, os apontamentos dêiticos, quando fazem

\footnotetext{
${ }^{4}$ Para uma análise das transformações da função da língua em geral e do diálogo em específico a partir do fim do século XIX, ver especialmente Birkenhauer, 2005, e sua leitura de Maeterlinck e Tchekhov.

${ }^{5}$ Como por exemplo nos textos tardios de Heiner Müller ou Elfriede Jelinek, ou nos textos recentes de Martin Crimp.

${ }^{6}$ Conforme o insight de que o teatro não representa o mundo empírico, mas oferece uma experiência de si mesmo enquanto parte integral desse mundo. Ou seja, como disse Heiner Müller, a dimensão utópica de um texto não está no nível da informação, do conteúdo, mas na sua forma. Essa configura a percepção do leitor/espectador e possivelmente inaugura uma experiência nova.

7 Ou seja, tratá-lo, de modo tradicional, enquanto "literatura".
} 
perceber o tempo e o espaço do evento teatral (e não da ficção, do mundo ficcionalizado); os traços poéticos e metateatrais do texto, quando permitem uma experiência de sua estrutura, menos enquanto discurso temático independente de sua apresentação teatral do que enquanto linguagem em ação. Exemplos desse empreendimento seriam, entre outros, as diferentes maneiras de usar estruturas córicas na escrita teatral contemporânea.

Marcado por procedimentos autorreflexivos, essa escrita provoca o leitor e espectador a experimentar a construção verbal do discurso (e da experiência humana relacionada a ele) no ato da apresentação teatral, seja essa real ou imaginada através do ato de leitura. Em outras palavras, o texto escrito incorpora na sua estrutura as possibilidades específicas que a apresentação lhe oferece: representar um material ficcional em dois eixos de comunicação e simultaneamente o processo da configuração desse material no meio da língua, no interior estrutural de sua materialidade. Ao exibir as palavras que transportam ações ficcionais, um texto configura uma relação de indagação mútua entre palco e plateia. Desse modo, ele expõe sua proposta de uma teatralidade tanto textual quanto cênica. ${ }^{8}$

Afirmar isso não implica que o texto proponha uma determinada encenação. Antes, insisto que uma leitura dele enquanto literatura ou enquanto "script" não consegue captá-lo em toda sua complexidade. A textualidade teatral contemporânea se assemelha a uma tessitura de vozes e modos de apresentação. Ela é estrutura ficcional, mas é também exposição de atos de fala e estruturas verbais performativas, exposição de padrões sociais e mentais no meio da língua (e não só da narrativa), reflexão sobre o papel da linguagem na percepção e na criação daquilo que chamamos de realidade. E no contexto teatral, a escrita implica também a proposta de uma relação estética entre os acontecimentos cênicos e o olhar dos espectadores, bem como uma configuração da relação social entre artistas-atores e espectadores. Acredito que a qualidade estética de um texto teatral contemporâneo é mais bem avaliada pela complexidade e

\footnotetext{
${ }^{8}$ Quando Guenoun afirma que, sob o impacto do cinema, o teatro assume como traço principal "o gesto da mostração", ele implicitamente configura o eixo palco-theatron como foco da comunicação teatral. "O teatro se tornou o seguinte: a colocação diante do observador do que não é filmável. [...] O teatro se torna o gesto da mostração, [...] na medida em que coloca diante do olhar, ali, sob os olhos, a coisa em si em sua fenomenalidade, o aparecer de seu estar-aí, o que poderíamos chamar de seu aparecer-aí. O aparecer-aí é a sua teatralidade." (2003, p.68) Estendendo as reflexões de Guenoun para o texto teatral, podemos perceber que "a coisa", no contexto da escrita teatral, não é só o material ficcional (seu conteúdo, o mundo representado) ou a própria língua (sua forma, o modo de aparecer na língua), mas também a relação entre ambos (o arranjo cênico perceptual) perante uma testemunha, o espectador.
} 
coerência com que este relaciona essas diferentes dimensões do que pelos critérios tradicionais da tipologia dramática.

Esses traços basicamente extradramáticos, então, constituem uma retórica do texto teatral que evidencia a dimensão performativa da escrita teatral, o "aparecer-aí da coisa [enquanto] sua teatralidade" (Guenoun, 2003, p.68). Em outras palavras, não há uma contradição, do meu ponto de vista, entre uma escrita constituir um texto e um evento, constituir representação e performatividade, estrutura semiótica e evento performativo. ${ }^{9}$ Trata-se de dois ângulos distintos sobre o mesmo fenômeno - a escrita teatral -, que exige diferentes modos de descrição. Me parece uma particularidade da escrita teatral, inserida na dupla comunicação teatral, poder jogar com a simultaneidade de textualidade e performatividade, de modo a constituir uma ambiguidade na qual a estrutura e a performatividade textuais constantemente se interrogam e até se subvertem. Ainda que nem sempre esta duplicidade constitutiva da dramaturgia escrita leve a essa ambiguidade, como atesta uma boa parte da dramaturgia chamada dramática e realista, é por causa de sua existência, que esses textos se oferecem a práticas de montagem que privilegiam, de diferentes formas, a performatividade teatral na representação dramática. Essas práticas seriam impensáveis sem as experimentações dramatúrgicas que quebraram com a hegemonia do eixo comunicativo intraficcional. ${ }^{10}$ De Maurice Maeterlinck a Heiner Müller, de Pirandello a Koltés e Lagarce, de Spegelbrud a Veronese, de Nelson Rodrigues a Plínio Marcos - a escrita que parece atender às necessidades de um mundo culturalmente pós-burguês é aquela que toma a precária simultaneidade entre traços representacionais e performativos, entre mundo ficcional e tempo/espaço da apresentação, como força formadora de sua criação textual e como oportunidade para criar experiências que incomodam e possivelmente deslocam o nosso modo habitual (burguês) de configurar as imagens apresentadas como objetivas e nossa posição perante elas como uma relação distante, fundamentada na separação entre observador e imagem.

A teatralidade textual, ou a ênfase (consciente) na apresentação da performatividade. Localizar a especificidade da escrita teatral na manipulação dos dois eixos de comunicação cria uma noção de textualidade teatral que complementa a

\footnotetext{
${ }^{9}$ De fato, qualquer fenômeno teatral apresenta ambos os aspectos. Sem aspectos semióticos, não seria compreensível, e sem aspectos performativos não se materializaria. Ver Fischer-Lichte 2001

${ }^{10}$ Por exemplo, no caso de Bob Wilson, uma influência fundamental é a dramaturgia de Gertrude Stein. O diretor alemão Frank Castorf foi influenciado pelas peças didáticas de Brecht e sua re-leitura e apropriação por Heiner Müller.
} 
teatralidade textual localizada unicamente na retórica da escrita. No caso da última, identifica-se no texto - e não só num texto dramático, mas também em textos líricos ou épicos - características performativas que mostram que o texto realiza na sua estrutura o que ele discursivamente afirma. Ou, como diz Guenoun, no trecho acima citado, elas mostram "diante do olhar, ali, sob os olhos, a coisa em si em sua fenomenalidade, o aparecer de seu estar-aí." (2003, p.68) O centro temático de textos com essa qualidade teatral está ancorado no funcionamento estrutural. Sua performatividade é teatral, um expor da teatralidade de sua língua. ${ }^{11}$ Nesse caso, os textos evidenciam uma preocupação com a própria linguagem segundo uma estética da produção e não da representação. ${ }^{12}$ Trata-se de uma escrita cuja dimensão representacional se localiza na produtividade de sua forma, nas tensões e rupturas inscritas nela, e não na qualidade de uma imitação dominantemente realista de um mundo empírico. Ou seja, uma escrita além do sujeito (burguês, autônomo e racional) enquanto fundador da língua. No contexto teatral, essa escrita se realiza em autores -formalmente bastante diferentes - como Valére Novarina, Elfriede Jelinek, ou Rainald Goetz. O que eles têm em comum é que à presença da figura humana, na forma do ator, se contrapõe um uso da língua na qual a noção de subjetividade centrada se esfacela. Antes, a língua expressa, em suas rupturas, dobras, tensões e sulcos estruturais, as diferentes forças sociais e libidinais que atravessam este sujeito. Quando surge uma instância de enunciação que diz "Eu", a estrutura do texto desmente a possibilidade de sustentar a sua estrutura fechada.

Dessa performatividade linguística pode-se dizer que assume características de teatralidade quando a escrita expõe na sua retórica uma consciência de sua estrutura e seus efeitos; quando ela expressa sua performatividade enquanto efeito de sua retórica. Ou seja, quando ela evidencia traços autorreflexivos, problematizando por meio de seu funcionamento estrutural o seu próprio status enquanto representação, indagando suas estratégias de interpelação do leitor. Essas características metateatrais, entretanto, dirigem a atenção do leitor/espectador não só para a situação de enunciação ficcional, mas também para o eixo theatron, para a situação da apresentação verbal.

\footnotetext{
${ }^{11}$ Me parece desnecessário aqui entrar numa discussão sobre a relação das noções de performatividade e teatralidade. Compreendo que toda teatralidade é acompanhada por uma performatividade com fortes traços autorreferenciais, enquanto nem toda a performatividade é, obviamente, teatral. O que torna uma ação performativa também uma ação teatral(izada) é a qualidade ostensiva, ou seja, autorreferencial, seja esta autoconsciente ou não.

12 Sobre a mimese da produção, na qual o funcionamento estrutural interno do fenômeno estético oferece as referências necessárias para vinculá-lo ao mundo empírico, ver Costa Lima, Luiz, 1980.
} 
No que segue, pretendo analisar traços dessa textualidade especificamente teatral e da teatralidade textual em textos teatrais brasileiros. Quero focar principalmente na função de estruturas corais de fala, nas indicações dêiticas e metateatrais. No caso das últimas, pretendo incluir tanto a situação do teatro no teatro, quando um uso mais estritamente linguístico da metateatralidade. Trata-se de exemplos que devido a sua descrição hegemonicamente realista (focando o texto enquanto narrativa ficcional dialogada cujos enunciadores são claramente personagens) se posicionam dentro de um contexto formal que poderíamos chamar com Szondi de tentativas de salvação do drama. Szondi (2001) já comentou que tanto o drama lírico quanto o teatro épico usam seus recursos para transformar a forma dramática, com o objetivo de poder salvar a hegemonia da ficção dialogada sobre a situação da apresentação teatral, ou seja, dos traços representativos sobre os traços apresentativos, performativos e situacionais, da prática teatral. ${ }^{13}$ Será a dramaturgia não-mais dramática ou pós-dramática que inverterá estas relações hegemônicas características para a hibridez da dramaturgia dramática não-rigorosa.

O drama da memória: traços de teatralidades não-dramáticas na dramaturgia de Mauro Rasi. O dramaturgo paulista Mauro Rasi (1949-2003) retrata em seus textos publicados ${ }^{14}$ convivências familiares, principalmente no interior paulista, nas décadas de 60 e 70. Com exceção de Viagem a Forli, as constelações familiares são praticamente iguais, bem como os hábitos peculiares dos indivíduos ${ }^{15}$ e até os nomes dos personagens. Guardadas as devidas proporções, podemos comparar o empreendimento dramatúrgico de Rasi com o universo de, por exemplo, William Faulkner. Busca fazer arte a partir de um universo geograficamente pequeno - a vida em uma cidade do interior de São Paulo -, ao detectar nos microconflitos dos indivíduos os macroconflitos da época.

\footnotetext{
${ }^{13}$ Com a ressalva de que Brecht criou com as peças didáticas um modelo de dramaturgia que coloca a situação teatral no mesmo nível que a situação ficcional, de modo que o gestus não só deve mostrar o personagem dentro de seu ambiente ficcional, mas também o teatro, o fazer teatral, dentro da situação social de encontro entre participantes. Entretanto, nas microestruturas ficcionais e no acabamento formal do texto verbal das peças didáticas, Brecht se atém à situações dramáticas e uma mimese representacional.

${ }^{14}$ Sob o título Trilogia foram publicados em 1993 os textos A Estrela do Lar (1989), A Cerimônia do Adeus (1987), Viagem a Forli (1993). O texto Pérola foi escrito e públicado em 1995

${ }^{15}$ Por exemplo, o fato de que eles soltam peidos. Este vício, bem como alguns momentos cômicos cuja hilaridade se baseia na distância entre a imagem erudita e civilizada afirmada pelas palavras dos personagens e seu comportamento chulo, mostram a relação de Rasi com o besteirol, gênero teatral que ele praticamente cofundou no Brasil.
} 
Nesse particular, há uma curiosa tensão nas peças entre os aspectos formais melodramáticos, o contexto político, e a materialização do imaginário dos personagens num plano surreal ou fantástico, que não rompe com a matriz melodramática no que diz respeito à natureza dos conflitos, mas dissolve as unidades de tempo e lugar. Por que a introdução do plano fantástico - com personagens que personificam anseios, desejos ou papéis sociais dos personagens realistas - no plano ficcional realista desse mundo familiar?

No centro dos conflitos e dos planos ficcionais - realistas e fantásticos - encontra-se como sua personagem principal a figura do filho, que quer acabar com a família, enquanto ainda vive dentro dela, ${ }^{16}$ mas também busca reconciliar-se com essa realidade, a partir do momento em que a deixa para trás. ${ }^{17}$ Não interessa aqui o aspecto biográfico do personagem do filho enquanto alter ego do autor, mas a pressão formal que a tensão entre realidade socialmente aceita e vida interior dos personagens exerce sobre o material ficcional.

Rasi cria na sua escrita um mundo claramente melodramático (o enfoque nos sentimentos dos personagens, viravoltas improváveis na narrativa, uma fraca causalidade lógica entre os acontecimentos da narrativa, o diálogo enquanto conversa e não enquanto ação etc.), e nesse sentido uma escrita extremamente tradicional, mas introduz nessa escrita, através da inserção de momentos fantásticos e metateatrais um jogo textual e cênico que acaba discutindo não só a psicologia e verdade interior de suas figuras, mas também as possibilidades do drama de fazer jus a conflitos provocados por um mundo no qual o indivíduo não se percebe mais como origem das ações, mas seu objeto ou, no máximo, mero acompanhante de uma dinâmica maior que ele.

Em Estrela do Lar, o filho Juliano cria uma peça dentro da peça, a partir de um texto de seu pai. Os personagens dessa peça fantástica permitem que se discuta o mundo psíquico reprimido pelos personagens no plano ficcional "real." Indiretamente, o plano fantástico oferece aos espectadores tomar consciência do papel formador que esse tipo de impulso exerce na sua própria realidade empírica.

Por exemplo, pode-se perceber essa mistura de uma escrita representacional convencional e um impulso crítico na cena em que o pai Hermes discorda da mãe que pede para que ele faça o filho "entender que realidade não tem nada a ver com teatro." (1993, p.47). Responde o pai: "Acho que a realidade é que imita o teatro. Faz de todos

\footnotetext{
${ }^{16}$ Em A Estrela do Lar e A cerimônia do Adeus, o filho é adolescente e estudante, respectivamente.

${ }^{17}$ Tanto Viagem a Forli quanto Pérola expõem esse motivo, embora somente os acotecimentos do segundo texto sejam ambientados no mundo familiar da cidade interiorana de Bauru/SP.
} 
nós, com ou contra nossa vontade, verdadeiros artistas. Não precisamos de 'script', nem de 'ponto', nem de 'contrarregra', 'diretor', nada...para representarmos diariamente os papeis que nos são distribuidas pela vida. [...] O mundo é o grande teatro onde apresentamos peças alegres ou tristes, sóbrias ou ridículas. E desse teatro, somos nós os artistas, sem o perceber." (ibidem.) Entretanto, diferentemente do pai, a empreitada do autor é direcionada para fazer com que os espectadores tomem consciência de seus papéis e do seu script, como nessa cena da peça dentro da peça, intitulada "O macho familiar" e escrita pelo filho Juliano, na qual misturam-se, no confronto entre a mãe Aspázia e o filho Juliano, a ficção realista e fantástica, marcadas pelas indicações cênicas do amigo Nielson:

(Juliano sai e retorna imediatamente como "Cássio", mistura de Dorian Gray com Rimbaud. Cássio bate a porta, violentamente.)

Aspázia - (Levantando-se) Quer tirar o robe do seu pai?

Nielson - "Cássio anda em direção ao bar."

Aspázia - O que você ta fazendo? Deixa esse copo aí, Juliano. Larga essa garrafa!

Cássio - (Volta-se para ela, petulante) E daí? (A luz sofre uma transformação. Entra música (Wagner). Aspázia incorpora Rita. Pode-se projetar o espectro de Rita sobre Aspázia e Aspázia como que dubla os movimentos. Enfim, o efeito deve ser mágico.)

Rita - E daí? Eu sou sua mãe e isso me interessa. Laura procurou por você e eu fiquei como um idiota sem saber onde você estava.

Nielson - "Cássio, irritado, sacode o gelo no copo." (Cássio executa a rúbrica )

$[\ldots]$

Nielson - (Soprando o texto para Rita) "Pelo menos..."

Rita - (Completando)... Eu não chego em casa a essa hora.

Nielson - (Baixinho) "Não vai me dizer onde esteve?"

Rita - (Continuando) Não faz mal...eu imagino.

Nielson - (A Rita) Prepara um drinque. (Ela executa. Acende um cigarro.)

Cássio - (Provocando-a) Quer mesmo saber?

Nielson - Pausa.

Cássio - Estive numa festa.

Nielson - Pausa

Cássio - De homens. [...] Só homens 
Nielson - Pausa (Protesta) Mas quanta pausa! A gente até esquece do que se trata.

Cássio - (cont.) E nós fizemos um monte de coisas que você pode muito bem imaginar, "mamãe". Quer que eu lhe conte?

Nielson - "Chocada"

Rita - (Chocada) Imundo!

$[\ldots]$

Aspázia - To fumando? (Entrega sem jeito o cigarro para Nielson. Voltase, preocupada, ao filho, mas sem encará-lo) Essa peça nova que você tá escrevendo... do que se trata afinal?

Essa cena é um bom exemplo das possibilidades analíticas que o desdobramento da comunicação nos dois eixos comunicativos permite. Através das didascálias faladas e sua execução imediatamente posterior, as ações são expostas enquanto resultado de um script. A entrada dos personagens fantásticos perante os olhos dos espectadores, bem como a saída da personificação, permite expor a cegueira dos personagens ficcionais - nesse caso, a mãe - a respeito das forças formadoras mais profundas do mundo do filho. Mas para os espectadores e leitores fica claro que o texto da peça dentro da peça incorpora um conteúdo psíquico habitualmente reprimido no mundo social e testa os limites desse mundo frente ao material psíquico que tenta ser expresso. A organização dos eixos comunicativos permite uma atuação além da noção de personagem, embora a temática das falas mantenha as figuras dentro desse universo e seu alicerce antropocêntrico.

Com a inserção de peça dentro da peça instala-se, portanto, uma discussão da relação dos dois planos no palco e, concomitantemente, uma estrutura textual que discute a relação entre esse texto como um todo, sua montagem cênica e a realidade empírica dos espectadores. Ou de modo mais geral, ao deslocar o foco da escrita teatral da elaboração de uma narrativa representacional para o modo de sua construção textual e cênica, a peça pode propor uma discussão da função do teatro no contexto empírico dos espectadores. Aproveitando as particularidades da situação teatral, a escrita de Rasi se mostra genuinamente teatral, mesmo que continue dominando um caráter dramático convencional, uma vez que a expressão de um conteúdo psíquico habitualmente reprimido por meio de uma peça dentro da peça não rompe na sua linguagem com os fundamentos do sujeito burguês. Ainda estamos perante um 
"Eu" que busca, através do arranjo metateatral, resgatar as bases para sua autonomia e racionalidade ameaçadas e recuperar seu domínio sobre a natureza interna.

Com esse arranjo, então, Rasi pode expressar a crise dos valores pessoais e sociais que atravessa o mundo pequeno-burguês e seus personagens e, simultaneamente, conter a crise num gesto de reconciliação tanto formal quanto de conteúdo. As cenas fantásticas ficam enquadradas na estética representacional do drama, sem confundir inconfortavelmente seu plano com o plano do realismo. Não surpreende que no final da trama o mundo realista segue intacto em seu rumo, enquanto o personagem Juliano para de escrever.

A Cerimônia do Adeus, escrita antes de A Estrela do Lar, mostra o momento logo antes da saída de Juliano do mundo familiar. Nessa peça, Rasi usou as figuras de Jean-Paul Sartre e Simone Beauvoir como dois personagens para expressar o imaginário de Juliano e interrogar este mundo interno do protagonista. Também há como paisagem atrás da varanda do quarto de Juliano uma silhueta de Paris, que muda de qualidades conforme os ânimos do protagonista. O aspecto formalmente mais usado, entretanto, é o fato de que Sartre e Beauvoir oscilam entre serem dois personagens fantasmas e simplesmente dois livros, embora falantes. Mas ao invés de usar essa ferramenta formal para desconstruir o sujeito fundador da fala, Rasi ofusca esse efeito ao aproveitar a duplicidade para tirar momentos de comicidade, como, por exemplo, no seguinte diálogo que inicia com uma tentativa de saída de Simone Beauvoir e Sartre para que ele possa falar para as massas brasileiras.

Juliano - (Barrando-Ihes o caminho) O senhor não poderá ir, Monsieur. Porque eu te emprestei.

(Pausa grave - Sartre e Simone trocam olhares aflitos)

Sartre - Você, o quê?

Juliano - (meio na defesa) Não pude negar. Ela não me emprestou o SaintExúpery?

Simone - (indignada) Você o trocou pelo "Pequeno Príncipe"?

$[\ldots]$

Sartre - Exija que ela não me faça 'orelha', hein? Nem me devolva todo cheio de anotações imbecis.

Juliano - Eu peço para ela te encapar...

Sartre - (Desesperado) Nãããããããoo! Ela é capaz de usar, de novo, aquele horrendo papel de presente cheio de florzinhas: eu fiquei parecendo uma puta. (1993, p. 145-146) 
Também nesta peça, no final os níveis se separam. Juliano se despede de Simone e Sartre, este último morrendo, para explicar na próxima cena para a mãe que vai embora, pois tem que viver a sua vida (idem, p.219). Entretanto, ao invés de se despedir, foge clandestinamente. Num epílogo final, ele nos é apresentado como dramaturgo bem-sucedido, que volta uma última vez para casa para mostrar seu carinho para a mãe e dizer Adeus. Como última ação cênica, as didascálias nos mostram a mãe, abrindo a janela para a varanda do quarto do filho e abrindo os braços "para a neve", ou seja, trata-se de um gesto de aceitação e reunião imaginária com o filho e seu mundo.

O conflito dramático, o agon actancial, é pífio nesses textos. Nada substancial muda nesse mundo. Somente a despedida do filho e sua reconciliação com a figura da mãe constituem acontecimentos que levam a narrativa, no último momento do texto, a outro patamar. Entretanto, como esse acontecimento não é resultado de um conflito ou embate dramático anterior, dificilmente podemos falar em transformação. Por outro lado, o caráter reconciliador do final não deixa com que a despedida do filho (ou sua parada de escrever em A Estrela do Lar) ganhe dimensões trágicas.

Ao aceitar o caráter estático do mundo interiorano, sem dinâmica agonal, o preço emocional pago pelo texto talvez seja a tendência a uma (doce?) melancolia. Mais grave, entretanto, me parece o preço estético que o objetivo da reconciliação final exige. Pois este preço consiste no fato de que os conflitos sociais e psicológicos que atravessam a peça e cujo protagonista principal é o filho Juliano, tais como a ditadura militar, o desejo juvenil por transformações, a busca pelo reconhecimento de desejos homossexuais, não conseguem transformar a forma da escrita. Eles formam um pano de fundo meramente ornamental, de modo que na dominância da escrita realista e melodramática com seus conflitos sentimentais de caráter fofoqueiro, a realidade social opressora manifesta sua hegemonia. Rasi não consegue detectar nos microconflitos dos personagens os macroconflitos da época de modo a romper com a subjetividade costumeira da época. ${ }^{18}$ Seus personagens não vivem na estrutura de sua língua as forças formadoras nem de seu conteúdo psíquico, nem de seu contexto

\footnotetext{
${ }^{18}$ A questão da homossexualidade ou de uma sexualidade polimorfa, por exemplo, poderia levar a uma escrita que apresenta um sujeito em fluxo e sem centro interno que não se entrega aos mecanismos de subjugação que a língua dominante exige. A escrita de Rasi não me parece criar essa outra língua, cheia de duplo sentidos e ambiguidades a respeito da construção de subjetividade e da posição do sujeito frente aos discursos sociais. Nesse sentido, Rasi fica aquém das possibilidades formais que seus experimentos formais indicam um tanto timidamente.
} 
histórico. Homossexualidade e ditadura se apresentam como mera citação, contexto externo que não adentra as estruturas de sentimento dos personagens. Como os conflitos temáticos não os fazem transgredir da subjetividade racional burguesa, estes não precisam adentrar a estrutura verbal e formal da escrita. ${ }^{19}$ Não há crise no interior da língua representacional, somente no interior da forma do drama.

Pois do ponto de vista do drama, nos textos de Rasi, o passado não existe como motivador de um presente cênico com ações transformadoras, mas como objeto de investigação e indagação por parte desse presente. Trata-se de peças de memória, de um trabalho psíquico interno que implica ao mesmo tempo resgatar as raízes do passado, reconhecer a estranheza em relação ao passado e reconciliar-se com a complexa realidade desse passado. Ou seja, o foco do texto cai não sobre o presente, mas sobre a relação com o passado, similarmente a textos de Ibsen ou Thornton Wilder. Mas diferentemente dos personagens de Ibsen, por exemplo, nem a trama nem os elementos metateatrais ou côricos mostram o que estava em jogo para o protagonista principal na sua luta interna entre ficar ou sair da família burguesa. De fato, esta luta em prol ou contra a família mal se manifesta nas ações da peça. Na forma da escrita, a desconstrução do mundo burguês nunca é uma questão ou um objetivo.

Desse ponto de vista, quando Juliano diz para o seu amigo Nielson "Eu tenho uma missão, Nielson: destruir a família. É minha razão de escrever." (Estrela do lar, 1993, p.35), estamos perante uma (auto-?) crítica do autor ao seu protagonista juvenil, pois, de fato, é o texto que tira seus efeitos cômicos da existência dessa família. A missão dos textos de Rasi, enquanto teatro da memória e de uma conciliação da figura do filho com a mãe, me parece ser oposta à de seu alter ego Juliano. A narrativa dos textos assemelha-se a uma salvação simbólica da família, mesmo em estado de ruínas, e principalmente uma salvação da figura das mães.

O que sobressai os conflitos presentes no seu desdobramento em um plano real e outro fantástico, são os momentos de comicidade. Eles atestam a cumplicidade entre

\footnotetext{
${ }^{19} \mathrm{O}$ mesmo pode-se constatar a respeito do mundo histórico em Viagem a Forli. Apesar de apresentar uma figura Juliano desdobrada em dois personagens, o velho e o jovem, eles não se confundem. O último monólogo de Juliano jovem, no qual ele admite os crimes que cometeu durante o Nazismo, novamente não questiona a subjetividade centrada e autônoma. Ao contrário, ele leva o personagem de volta a essa, quando assume sua responsabilidade de ter feito "tudo para sobreviver" (1993, p.307). O monólogo longo de três páginas não se transforma numa confissão impessoal, no qual o indivíduo assumiria características de sujeito anônimo, embora filho de seu tempo, e a fala qualidades de uma fala de coro. A tentativa de salvar o drama, de não levar o desdobramento do personagem e a isolação da fala para além dos limites da narrativa dramática, leva ao salvamento da subjetividade burguesa.
} 
os personagens e entre a figura do autor e seus personagens, pois por meio deles os textos expressam uma adoração pelas habilidades comunicativas das figuras, que Juliano descreve como capacidade de transformar "banalidade em clímax, a rotina em efeito especial." (1993, p.33) ${ }^{20}$ Essa fascinação acaba contaminando e diluindo os impulsos de uma crítica social.

A crítica é feita não só de uma forma cômica, mas por meio de um arranjo cênico predominantemente representacional, de modo a oferecer aos leitores e espectadores cumplicidade com o mundo criticado. Não é preciso deixar a família para trás, diz a forma do texto, se ela ainda serve como material relevante e interessante para criar risos e lágrimas. Principalmente a compaixão pela figura da mãe dentro dessa família (enquanto colaboradora, conspiradora e vítima dessa estrutura) é maior do que o impulso de olhar para outros modelos sociais e de subjetividade. ${ }^{21}$ Por meio das ferramentas não-dramáticas de sua escrita, Rasi consegue incorporar o drama da memória e simultaneamente criar efeitos de entretenimento crítico dentro dos limites do drama. Entretanto, mesmo que o drama da memória não caiba nos limites do drama rigoroso, as exigências de uma reconciliação com o status quo fazem que não se incorpore formas estéticas marcadas por novas subjetividades, relações sociais e outras formas estéticas da escrita teatral. Me parece que era menos sua morte prematura do que a fidelidade nostálgica com o mundo da pequena burguesia interiorana, com os alicerces emocionais e filosóficos da família burguesa e a subjetividade que a sustenta, que inibia Rasi de explorar e radicalizar as sementes formais não-dramáticas presentes em seus textos, de levar o conflito para além da psicologia e dentro da relação entre sujeito e língua onde se criaria uma escrita mais performativa do que representacional, jogando mais radicalmente com os dois eixos de comunicação. ${ }^{22}$

O drama libidinal: Alcides Nogueira. Entre 1989 e 1998, Alcides Nogueira escreveu sua "Trilogia do Discurso Moderno" sobre vida e arte de artistas modernistas

\footnotetext{
${ }^{20}$ É claro que uma montagem pode desequilibrar um pouco essa qualidade convencional da construção da trama.

${ }^{21}$ O texto Pérola é um bom exemplo disso, no qual o elemento transformador, o filho, volta para casa na função de uma mera testemunha para observar o jogo da família presa a interações do passado. Mais uma vez, uma peça mostra as lembranças do filho. Infelizmente, os textos de Rasi não tratam das lutas do filho por uma transformação pessoal e social, que, afinal, são lutas não só dos gays dos anos 80, mas da geração inteira das "Direitas Já!".

22 Nesse contexto, cabe lembrar que o último texto que trata desse universo, Pèrola, é pouco mais que uma reprise de traços da trilogia escrita anteriormente. Em termos formais, não constamos um desenvolvimento formal durante os anos 1987-1995. Ao contrário, percebo uma consolidação da técnica de flashback, da inserção de momentos épicos, num projeto de resgate da memória que se modifica ou radicaliza.
} 
europeus: Ópera Joyce (1989), Gertrude Stein, Alice Toklos \& Pablo Picasso (1995) e Pólvora e Poesia (1998), este último texto sobre a relação entre Paul Verlaine e Arthur Rimbaud. A trilogia atravessa não só um interesse na estética modernista, mas uma busca de encontrar na linguagem dessa vertente um estímulo para expressar na escrita teatral de forma mais arrojada verdades interiores de um indivíduo que está vivendo uma situação de limite entre hipocrisia e confissão. A trilogia expressa o choque das figuras teatrais com suas verdades interiores e com os padrões estéticos e morais socialmente estabelecidos. Implicitamente, encontramos nos experimentos formais dessa trilogia uma busca por modos não-convencionais de alinhar a estética da escrita teatral a um coming out emocional que ultrapasse qualquer moralismo social. ${ }^{23}$ Trata-se, então, de um projeto estético que não se contenta em falar sobre esses desejos e paixões habitualmente reprimidos, mas que permite que eles penetrem a forma da escrita para que essa expresse os vetores libidinais enquanto forças formadoras estéticas. Pois seria uma contradição interna se o autor expressasse em seu texto o momento de ruptura com a subjetividade burguesa, com as exigências de controle racional e de dominação da natureza interna e externa, por meio de uma língua social e teatral que é sintoma dessa ordem e de seus valores.

Curiosamente, a primeira peça da trilogia, Òpera Joyce, aparenta os traços não-dramáticos mais radicais da trilogia, ${ }^{24}$ principalmente no que concerne a um uso côrico e até um uso não-figurativo da língua. Podemos perceber nesses traços as influências das convenções formais da ópera, como o título já indica. Cria-se, por meio desse uso da língua mais expositivo que representacional, figuras cênicas que não se submetem totalmente ao conceito do indivíduo, do personagem psicológico do drama. Concomitantemente a esse uso, percebe-se uma ênfase no eixo comunicativo palco-theatron, exatamente pelo fato das falas exporem por meio dos traços côricos as estruturas verbais, o plano da língua. Isso não é para dizer que o interior dos personagens não apareça nas falas. Antes, ele não aparece como assunto, senão como aspecto e efeito da estrutura

\footnotetext{
${ }^{23}$ Em entrevista via Chat, Alcides afirma não só que o teatro oferece certas liberdades formais que outros meios não permitem, como também declara que com a trilogia chegou a um outro patamar de radicalidade pessoal. "Acho que esse dilaceramento sempre houve. Estava oculto ou preservado em algum ponto, muitas vezes recoberto pela poética da minha palavra (que não abandonei nem pretendo, pois gosto), mas agora é tudo ou nada. Não tenho o que perder. Não vou deixar passar a vida sem que as pessoas saibam que o Alcides Nogueira pensa desse jeito." In: http://blocoson. blogspot.com/2009/12/bate-papo-com-alcides-nogueira.html, acesso em 12/11/2010.

${ }^{24}$ O próprio Alcides concordou com essa constatação numa entrevista cedida a mim em 14.05.2010.
} 
verbal, o que lhe confere uma característica coletiva. Desse modo, o texto consegue apresentar os impulsos libidinais dos personagens ficcionais denominados James Joyce, Nora Joyce e Stephen Dedalus como aspectos de uma trajetória coletiva. A identificação oferecida ao público é menos com os conflitos desses personagens enquanto indivíduos, mas com a dinâmica libidinal enquanto jogo entre repressão, sublimação e paixão ardente. ${ }^{25}$ Devido à manipulação dos eixos comunicativos, assim a tese aqui , essa dinâmica acontece mais no interior da linguagem textual e cênica do que entre os personagens ficcionais.

Focar o eixo palco-theatron e o "gesto de mostração", como diz Guenoun, costuma evocar como centro da estética teatral não o mundo ficcional ausente, mas as ações cênicas presentes, ou seja, a presença performativa dos elementos cênicos, tais como movimento, fala, luz, adereços etc. O que interessa continua sendo em parte sua dimensão simbólica. Entretanto, sobrepõe-se a essa dimensão a camada das qualidades sensoriais e sinestésicas, que também possuem um acabamento formal. Conforme a percepção de Luiz Costa Lima acerca da estética da produção, podemos dizer que é essa forma da performatividade textual e cênica que permite e orienta a criação da dimensão simbólica. Como o texto de Alcides organiza o foco na performatividade, tanto da cena quanto do próprio texto?

A importância desse eixo no texto Ópera Joyce fica claro já no Prelúdio que abre a primeira cena. As didascálias mostram ações cênicas que se mantêm, de modo ambíguo, entre representação e performatividade, entre um foco na ficção e outro na cena enquanto local de ações concretas no presente. Diz o texto:

ENQUANTO O PRELÚDIO É EXECUTADO, JAMES ESTÁ SE BARBEANDO.
NORA FAZ A MALA DE JAMES, COLOCANDO NELA VIDRINHOS,
PANINHOS, LENCINHOS, CARALHINHOS...UM GRANDE LIVRO SOBRE O
PIANO (O ULYSSES DE JOYCE). EM OUTRO PONTO, DEDALUS TAMBÉM
SE BARBEIA, COM UMA MALA TAMBÉM ABERTA, COM AS MESMAS
COISAS QUE NORA COLOCA NA MALA DE JAMES. AO INVÉS DO LIVRO,
PERTO DE DEDALUS, UMA GARRAFA DE WHISKY. JAMES E DEDALUS
USAM ROUPÕES IGUAIS, E SEGURAM UMA VASILHA PEQUENA, ALÉM DO
PINCEL DE BARBEAR E NAVALHA. NORA USA UMA ROUPA TOTALMENTE
DISCRETA. O PRELÚDIO TERMINA E NORA, JAMES E DEDALUS ENTOAM:

OS TRÊS

Introibo ad altare Dei! (p.29)

\footnotetext{
${ }^{25}$ No final do texto, esse caráter transpessoal e coletivo do trama (AQUI SERIA "DO TRAMA", "DA TRAMA" OU "DO DRAMA"?) é mencionado claramente por um homem anônimo em Off que denomina o espetáculo "uma imoralidade nacional em três orgasmos...com James Joyce, Nora Joyce e Stephen Dedalus!!!" O que importa aqui é que essa qualificação é afirmada pelo o acabamento formal do texto. E os três orgasmos são, em primeiro lugar, realizados através da estrutura textual e do texto em cena!
} 
Trata-se de ações que misturam aspectos representacionais - Nora está preparando a mala para seu marido Joyce ir ao trabalho - e performativos - as ações são "executadas", os dois personagens masculinos realizam a mesma ação ("barbear-se") sem nenhum nexo de narrativa, vestidos de modo igual. Trata-se, então, do prelúdio de um ritual, como afirma logo a declamação conjunta "Introibo ad altare Dei!", fórmula inicial da Missa Romana. $O$ foco está na interação de três figuras cênicas que assumem diferentes posições nessa missa libidinal entre submissão (livro), transgressão e libertação dos instintos (a garrafa de whisky). ${ }^{26}$ Logo de início, o texto coloca seu funcionamento cênico (e consequentemente a peça proposta por ele) fora do contexto representacional realista e assume um gesto de mostração ritualístico. $A$ segunda cena, intitulada CORO DE ABERTURA, continua com esse gesto ao alternar falas em conjunto ("Subam, subam, jesuítas execráveis" p.30), interações verbais altamente formalizadas ("NORA: James Joyce vai partir. É um caixeiro-viajante. - JAMES: Nora? - NORA: Sim, James. - JAMES: Nora? - NORA: Sim, James. - JAMES: É uma dama suspirante! - OS TRÊS: E ele? O outro? Quem será? - DEDALUS: Stephen Dedalus, pronto pra atacar." p.30-31)), e diálogos descritivos (NORA: "James Joyce vai partir. - JAMES: Nora Joyce vai ficar. - OS TRÊS: Nora vai tocar. - NORA: James vai vender vidrinhos, paninhos, caralhinhos, tudo enfim! - JAMES: Nora ficará sentada. Ao piano, sempre sentada. Esperando, esperando entrar um dia no Coro do Tabernáculo de Deus!" p.31) e comentários, cujo endereçado são menos os outros 'personagens' do que o espectador, como no comentário de Dedalus à descrição anterior: "Uma vida que é uma merda!" (p.31).

Até uma cena como a de despedida entre Nora e James (Cena 3, p. 35-37) é transformada em uma estrutura litúrgica por meio de recursos que distanciam fala e apresentação de um modo representacional. As didascálias, por exemplo, indicam um modo "cantado" de recitar as falas ("Até a partida dele, cantam em dueto." p. 35). Joyce usa repetitivamente a palavra "Ebben", que significa "Meu bem" em flamengo, para se dirigir à Nora, como se ambos fossem personagens de um livro dele. As falas de ambos são marcadas por aliterações e rimas internas, como em NORA: "Ha, lazer, laser ou lézard! Cansei de tanto chinela arrastar...Por que você não gosta do lar, James?" (p. 36).

\footnotetext{
${ }^{26}$ Poderia-se criticar a escolha dos objetos por seu caráter clichê e por serem explicativas demais e desnecessárias ao longo do texto, uma vez que as figuras logo revelam seus impulsos principais, mas este tipo de crítica estética não vem ao caso aqui.
} 
Além dessas características no nível da microestrutura do texto, encontramos uma série de indicações para que ações cênicas sejam realizadas de modo formalizado e artificial. Os longos monólogos, igualmente estilizados por meio de um acabamento formal poético, também contribuem para uma estética que coloca em cena estados psíquicos como forças actancias, sem que haja necessidade de um personagem psicológico. Desse modo, o "Eu" que aparece nas falas das três figuras não é um eu dominante e racional, dono de si mesmo, mas um eu móvel, como se fosse uma boia sobre as ondas verbais do texto, e nisso um reflexo de impulsos libidinais que se expressam através dessa estrutura textual, como, por exemplo, quando Nora fala sem ponto e vírgula: "Eu era uma Flor da montanha sim quando eu punha a rosa em minha cabeleira como as garotas andaluzas costumam ou devo usar uma vermelha sim e como ele me beijou [...]" (p.41) Ou Dedalus: "Luzes, luzes, luzes e sem ação! Som, som, som e sensação! Eu quero bundas nas janelas. Eu quero peitos nas tramelas. Eu quero gargalhadas e champanhes e heroína na veia do otário. Eu quero um puta horário. Pra santa visitação ao oráculo ao cenáculo ao senado ao safado senhor da serraria da sortuda sinfonia da chifruda putaria que se chama este país! [...]" (p.48)

A dominância do acabamento formal sobre seu conteúdo de informação distancia as falas da comunicação intraficcional. Trata-se de procedimentos mais sutis e engenhosos do que o costumeiro aparte, o endereçamento direto do público para chamar sua atenção sobre um detalhe cênico ou para quebrar com sua identificação automática. ${ }^{27}$

Seria errôneo pressupor que Alcides limpa seu texto de todas as alusões representacionais, tais como diálogos bem próximos a uma fala cotidiana entre duas pessoas. Entretanto, eles são sempre quebrados por esses procedimentos poéticos que os distanciam novamente do registro realista cotidiano. A poesia desorganiza a língua habitual e representacional, tal como expressa nas falas cotidianas. Desse modo, o texto expressa na sua interação entre língua padronizada e língua pessoal e poética, entre a língua socialmente reconhecível e portanto representacional e a língua performativa, o conflito entre repressão e transgressão, entre sociabilidade e ruptura libidinal.

Nos outros textos da Trilogia, Alcides não conseguiu (e talvez nem almejou) esse entrosamento entre forma e conteúdo. Em Gertrude Stein, Alice Toklas \& Pablo Picasso, a forma do texto se mantém nos limites de um texto representacional dramático, com

\footnotetext{
${ }^{27}$ Alcides usa esse recurso uma vez, para tirar Dedalus, revoltado e com ciúmes, de cena, sem que haja realmente uma necessidade dramatúrgica: "Sacanas!!! (Pausinha) Aqui, segundo a rubrica do autor, Dedalus sai!' DEDALUS SAI. NORA E JAMES SE ENCARAM." Trata-se, em primeiro lugar, de um "efeito especial", de uma prova de seu conhecimento de truques dramatúrgicos de como incluir didascálias nas falas dos personagens.
} 
pequenos momentos de ruptura e endereçamento direto do público. Entretanto, a estética representada por Stein e Picasso não marca presença no texto. Ela é meramente assunto das conversas. No texto Pólvora e Poesia sobre a relação entre Verlaine e Rimbaud, estamos novamente perante um texto de forte caráter poético, repleto de metáforas, que mistura nas ações cênicas momentos dramáticos (o encontro de Verlaine e Rimbaud), épicos (a recapitulação do tiro que Verlaine deu em Rimbaud) e líricos (o encontro dos personagens com seus fantasmas interiores). Diferente de Òpera Joyce, no entanto, não estamos perante de um texto que dissolve os personagens psicológicos em mascaras verbais e posições além do indivíduo burguês. O conflito dos dois poetas é um conflito amoroso como acontece entre qualquer casal, com a única diferença que eles dispõem de recursos retóricos mais rebuscados. A característica mais dramática desse texto se deve ao uso ilustrativo desses recursos. Eles servem em primeira lugar para representar os conflitos psicológicos dos poetas. Desse modo, semelhante ao texto Gertrude Stein, Alice Toklas \& Pablo Picasso, a linguagem do texto Poesia \& Pólvora fica aquém das formas estéticas e das subjetividades embutidas nelas, tais como foram propostas pelos dois poetas na sua obra lírica.

Considerações finais. Òpera Joyce deixa claro que a consideração da estética de um texto teatral não propõe uma determinada interpretação e muito menos a submissão da cena às qualidades textuais, no que diz respeito ao seu possível significado, por exemplo. Mas também ficou patente que um diretor precisa encontrar soluções cênicas para o jogo textual entre representação e performatividade que atravessa esse texto. Como expressar em cena, por exemplo, essa subjetividade que oscila constantemente entre aproximação e distanciamento de um personagem, sem nunca fundir-se ou separar-se dele? Um foco temático no texto, como proposto por Tuna Dwek na sua introdução, quando diz que ele prova que "em amor não há pudor" não consegue captar as implicações cênicas do texto. Lê o texto principalmente como literatura. Analisar o jogo com os eixos comunicativos, que textos teatrais realizam, permite não só valorizá-los enquanto genuinamente teatrais, mas também libera a imaginação cênica a respeito deles. Permite detectar em textos predominantemente dramáticos as sementes de uma estética e uma ética não-dramática e não-burguesa. Possibilita inclusive conceber uma relação entre texto e cena, na qual a cena pode ser um espaço para expor as palavras, o funcionamento do texto, enquanto representação não de interações entre indivíduos, mas de estruturas mentais coletivas. 
Com a discussão desses dois autores brasileiros, eu pretendi, entre outros, mostrar que a inexistência de uma dramaturgia não-dramática no Brasil é, em parte, um mito e fruto de um mal-entendido que exige que o não-dramático se realize como forma pura, somente enquanto tessitura de vozes, portadores de fala, mas não dentro de um contexto figurativo. Igualmente, a ideia de que um texto precise somente romper com as unidades do tempo, do lugar e da ação, para constituir-se enquanto não-dramático ou, pior ainda, "pós-dramático", é principalmente resultado de uma falta de conhecimento dramatúrgico genuinamente teatral. É possível argumentar que a ruptura com essas unidades constitui um texto de traços não-dramáticos. O que não se costuma perceber ou enfatizar é que esse "não-dramático" de modo algum implica necessariamente uma ruptura com o modo representacional tão habitual do drama: a dominância da comunicação intra-ficcional entre personagens atrás de uma quarta parede com o público na posição de voyeur.

É correto que o drama sempre conhecia procedimentos para perfurar essa quarta parede. Mas enquanto o aparte ou até o monólogo são furos momentâneos no tecido dramático, que não desestabilizam a validade da quarta parede e a importância dominante do mundo ficcional, a escrita predominantemente performativa realiza uma oscilação entre os dois eixos comunicativos que acaba com a posição firme do leitor/ espectador. Devido a essa oscilação, esses discursos textuais se tornam eventos. Enquanto tais, fazem com que o leitor/expectador possa experimentar a materialidade da escrita enquanto algo dinâmico e produtivo, tanto na página quanto no palco.

O problema do conhecimento dramatúrgico aqui no Brasil,, ${ }^{28}$ e o desafio para a dramaturgia brasileira, me parece ser ligado hoje em dia aos modos de produção de textos e montagens teatrais. O teatro é uma arte minoritária, e a dominância da teledramaturgia é tal que o imaginário de jovens autores é pouco instigado para modelos dramatúrgicos que brincam com as possibilidades teatrais, seu espaço ao mesmo

\footnotetext{
${ }^{28}$ Em conversa com Luis Alberto de Abreu (15/03/2010, 6:40min-8:00min, arquivo pessoal do autor), ele afirmou que achava extremamente difícil achar interlocutores para seus projetos dramatúrgicos e que a situação da dramaturgia brasileira Ihe parecia muito frágil desde o fim da ditadura. "Da minha geração, os meus colegas ou tiveram uma carreira muito curta, ou foram para a TV. Eles não tiveram um projeto de pesquisa, de pesquisa dramatúrgica, de uma linguagem teatral. [...] A teoria da dramaturgia é muito pouco pesquisada, muito pouco conhecida, inclusive pelos próprios dramaturgos. Nessa área, é um trabalho muito solitário, eu tive um trabalho muito solitário. [...] Nós temos o contexto de que a dramaturgia estava fragilizada. E temos o contexto do esgotamento do realismo, do tipo do Arena. E aí temos essa abertura, essa abertura total. Eu acho que esses três fatores contribuíram demais, demais para não haver uma reflexão profunda na dramaturgia e na forma teatral que pudesse responder a este momento."
} 
tempo mais humano, pois presencial, e mais abstrato, pois nunca real e realista. A sobrevivência de um autor teatral está ou na teledramaturgia ou no jornalismo. Não há nem estímulos financeiros suficientes, via bolsas contínuas, nem estímulos de montagem para textos inéditos para criar uma vertente forte de dramaturgia formalmente contemporânea no Brasil. Os exemplos de Mauro Rasi e Alcides Nogueira mostram que sementes de uma dramaturgia não-dramática no Brasil não faltam. 0 que falta é uma política de regá-las. A esperança de Bárbara Héliodora (in Rasi, 1993, p.14) de que o trabalho de Mauro Rasi fosse estímulo para que "não haja mais interrupçoes em nossa dramaturgia" foi vã.

\section{Referências}

ABIRACHed, Robert. La crisis de personaje en el teatro moderno. Trad. Borja Ortiz de Gondra. Madrid: Associación de Diretores de Escena de España, 1994 (original 1978).

BiRKENHAUER, Theresia. Schauplatz der Sprache - das Theater als Ort der Literatur. Maeterlinck, Čechov, Genet, Beckett, Müller. Berlin: Vorwerk8, 2005.

Costa LimA, Luiz. Mimesis e Modernidade: A forma das sombras. Rio de Janeiro: Graal, 1980

FISCHER-LICHTE, Erika. Ästhetische Erfahrung: das Semiotische und das Performative. Tübingen: Francke, 2001.

NoguelRA, Alcides. Trilogia. São Paulo: Imprensa Oficial, 2005. Disponível em http://aplauso. imprensaoficial.com.br/edicoes/12.0.813.102/12.0.813.102.pdf

PFISTER, Manfred. Das Drama. München: Fink, $1988^{5}$.

RASI, Mauro. Trilogia. Rio de Janeiro: Relume Dumará, 1993.

. Pérola. Rio de Janeiro: Record, 1995.

RYNGAERT, Jean-Pierre. Introdução à analise do teatro. São Paulo: Martins Fontes, 1996.

Szond, Peter. Teoria do drama moderno. São Paulo: Cosac \& Naïfy, 2001, original alemão 1967. 